\title{
ОСОБЛИВОСТІ РОЗВИТКУ КРИТИЧНОГО МИСЛЕННЯ УЧНІВ БАЗОВОЇ ШКОЛИ У ВИВЧЕННІ МАТЕМАТИКИ
}

\author{
Остапенко А. В. \\ здобувач третього (освітньо-наукового) рівня вищої освіти кафедри \\ початкової і професійної освіти, Харківський національний педагогічний \\ університет імені Г. С. Сковороди, м. Харків, Україна
}

Стаття присвячена аналізу та визначенню особливостей розвитку критичного мислення учнів на уроках математики. Автором розглянуто основні етапи розвитку методу критичного мислення учнів (виклик, осмислення, стадія осмислення, рефлексія) та специифіку його впровадження у процес вивчення математики учнями базової иколи.

Ключові слова: учень, критичне мислення, розвиток, урок математики, базова школа.

The article is devoted to the analysis and definition of features of development of critical thinking of pupils at lessons of mathematics. The author considers the main stages of development of the method of critical thinking of students (challenge, comprehension, stage of comprehension, reflection) and the specifics of its introduction into the process of studying mathematics by elementary school students.

Key words: student, critical thinking, development, mathematics lesson, basic school.

Аналізуючи реалії сучасного життя, формується актуальність проблеми, що доцільно виховувати особистість незалежну, вільну, здатну самостійно осмислювати явища навколишньої дійсності, відстоювати власну думку перед будь-ким і будь-де. Зазначене надає підстави стверджувати, що основи цих якостей мають закладатися ще в базовій школі, а потім продовжувати розвиватися у закладі вищої освіти. Сучасна школа має формувати активність учнів до вирішення важливих питань життя колективу, формувати, висловлювати і відстоювати свою думку, поважати думку інших. Одним із елементів розвитку сучасної дитини є розвиток критичного мислення [1, с. 94 -98].

Що таке критичне мислення? Це процес аналізу, синтезування й обгрунтовування оцінки достовірності інформації; властивість сприймати ситуацію глобально, знаходити причини і альтернативи; здатність генерувати чи змінювати свою позицію на основі фактів й аргументів, 
Розділ І. Ціннісні орієнтири духовно-інтелектуального виховання, розвиток духовно-інтелектуальних якостей особистості в умовах співпраці й інклюзії

коректно застосовувати отримані результати до проблем і приймати зважені рішення - чому довіряти та що робити далі [5, с. $124-129]$.

Іноді до критичного мислення ставляться як до звичайного процесу мислення, і досить часто плутають з простим запам'ятовуванням, розумінням складних ідей, творчим мисленням.

Критичне мислення - складне й багаторівневе явище. Мислити критично означає вільно використовувати розумові стратегії та операції високого рівня для формулювання обгрунтованих висновків і оцінок, прийняття рішень $[2 ; 3]$.

3 педагогічної точки зору критичне мислення - це комплекс мисленнєвих операцій, що характеризується здатністю особистості:

- аналізувати, порівнювати, синтезувати, оцінювати інформацію з будь-яких джерел;

- бачити проблеми, ставити запитання;

- висувати гіпотези та оцінювати альтернативи;

- робити свідомий вибір, приймати рішення та обгрунтовувати його $[4 ; 5]$.

Одним 3 провідних чинників розвитку критичного мислення $€$ мотивація учня до навчання. Доцільно, розпочинаючи з базової школи вивчати математику, використовуючи елементи логіки.

Проведений аналіз наукової літератури провідних учених у цьому напрямі $[1 ; 4 ; 5]$, надає підстави визначити основні етапи розвитку методу критичного мислення учнів, зокрема такі, як-от: виклик, осмислення, стадія осмислення, рефлексія.

Визначаючи специфіку розвитку методу критичного мислення учнів при вивченні математики в базовій школі на кожному етапі зазначимо, що виклик містить стимулювання учня до навчальної діяльності, активізацію набутих знань; осмислення (набуття та класифікація навчальної інформації); стадія осмислення (підвищення інтересу до вивчення математики); рефлексія (набуття нових знань з переосмисленням вже набутих) [2; 3; 4].

Слід зазначити також, що особливістю вивчення уроку математики в базовій школі є те, що майже на кожному занятті є вивчення нової навчальної інформації. А це означає, що критичне мислення учнів має розвиватися неперервно та послідовно з реалізацією всіх етапів розвитку методу критичного мислення учнів (виклик, осмислення, стадія осмислення, рефлексія). 


\section{Список використаних джерел:}

1. Жерновникова О. А. Дидактична підготовка майбутніх учителів математики до проектування навчальної діяльності старшокласників: теоретичний та методичний аспекти : монографія. Харків : Видавець Іванченко I.C., 2015. 404 c.

2. Маркова I. С., Біловол Г. О. Урок математики в сучасних технологіях: теорія і практика. Розвиток критичного мислення. Харків : вид. група «Основа», 2007.

3. НУШ «Нова Українська Школа». URL: https://nus.org.ua/articles/krytychnemyslennya-2/ (дата звернення 20.10.2021).

4. Сиротенко Г. О. Сучасний урок: інтерактивні технології навчання. Харків : Основа, 2003. 312 с.

5. Технології розвитку критичного мислення учнів / Кроуфорд А., Саул В., Метьюз С., Макінстер Д.; наук. ред. О. І. Пометун. Київ : Плеяда, 2006. $220 \mathrm{c}$. 